\title{
Cytotoxic and apoptotic effects of six herbal plants against the human hepatocarcinoma (HepG2) cell line
}

\author{
Sasipawan Machana ${ }^{1}$, Natthida Weerapreeyakul ${ }^{2}$, Sahapat Barusrux³ ${ }^{3}$ Apiyada Nonpunya ${ }^{1}$, \\ Bungorn Sripanidkulchai ${ }^{2}$ and Thaweesak Thitimetharoch ${ }^{2}$
}

\begin{abstract}
Background: Six plants from Thailand were evaluated for their cytotoxicity and apoptosis induction in human hepatocarcinoma (HepG2) as compared to normal African green monkey kidney epithelial cell lines.

Methods: Ethanol-water crude extracts of the six plants were tested with neutral red assay for their cytotoxicity after 24 hours of exposure to the cells. Apoptotic induction was tested in the HepG2 cells with diamidino-2phenylindole staining. DNA fragmentation, indicative of apoptosis, was analyzed with agarose gel electrophoresis. Alkylation, indicative of DNA damage, was also evaluated in vitro by 4-(4'-nitrobenzyl) pyridine assay.

Results: The extract of Pinus kesiya showed the highest selectivity (selectivity index $=9.6$ ) and potent cytotoxicity in the HepG2 cell line, with an $\mid C_{50}$ value of $52.0 \pm 5.8 \mu \mathrm{g} / \mathrm{ml}$ (mean \pm standard deviation). Extract of Catimbium speciosum exerted cytotoxicity with an $\mathrm{IC}_{50}$ value of $55.7 \pm 8.1 \mu \mathrm{g} / \mathrm{ml}$. Crude extracts from Glochidion daltonii, Cladogynos orientalis, Acorus tatarinowii and Amomum villosum exhibited cytotoxicity with $I C_{50}$ values ranging 100 $500 \mu \mathrm{g} / \mathrm{ml}$. All crude extracts showed different alkylating abilities in vitro. Extracts of $P$. kesiya, C. speciosum and C. orientalis caused nuclei morphological changes and DNA laddering.
\end{abstract}

Conclusion: The extracts of $C$. speciosum, C. orientalis and P. kesiya induced apoptosis. Among the three plants, $P$. kesiya possessed the most robust anticancer activity, with specific selectivity against HepG2 cells.

\section{Background}

Natural products have been used as anticancer agents [1], such as vincristine and vinblastine from Catharanthus roseus [2], taxol and docetaxel from Taxus brevifolia [3] and camptothecins from Camptotheca acuminata [4]. Even vegetables and fruits may help reduce the risk of cancer in humans $[5,6]$.

We selected six Thai plants for this study, namely Glochidion daltonii, Cladogynos orientalis, Catimbium speciosum, Acorus tatarinowii, Amomum villosum and Pinus kesiya which are also native to China. This study investigates the cytotoxicity of these six plants against the human hepatocarcinoma (HepG2) cell line

\footnotetext{
* Correspondence: natthida@kku.ac.th

${ }^{2}$ Center for Research and Development of Herbal Health Products, Division of Pharmaceutical Chemistry, Faculty of Pharmaceutical Sciences, Khon Kaen University, Khon Kaen 40002, Thailand

Full list of author information is available at the end of the article
}

compared to the normal African green monkey kidney epithelial (Vero) cell line.

\section{Methods \\ Chemicals and reagents}

Cell culture media, including Dulbecco's modified Eagle's medium (DMEM), foetal bovine serum (FBS) and penicillin and streptomycin, were purchased from GIBCO $^{\circledR}$ (Invitrogen, USA). Acetonitrile (HPLC grade, Fisher Scientific, UK), ortho-phosphoric acid (analytical grade; BHD, UK) and ultrapure water from a Milli-Q system (Millipore, USA) were used for the mobile phase preparation. The reference standards, namely gallic acid, chlorogenic acid, catechin, epicatechin, caffeic acid, vanillic acid, vanillin, coumaric acid, ferulic acid and quercetin, were purchased from Sigma-Aldrich (USA). Dimethylsulfoxide (DMSO), ethidium bromide and the fluorescence dye 4',6-diamidino-2-phenylindole (DAPI)

\section{Ciomed Central}


were purchased from Sigma-Aldrich (USA). Sodium bicarbonate $\left(\mathrm{NaHCO}_{3}\right)$, neutral red, 4-(4'-nitrobenzyl) pyridine (NBP) and a standard anticancer drug (melphalan) were purchased from Sigma-Aldrich (USA). A FlexiGene DNA kit was purchased from QIAGEN (Germany); agarose (molecular grade) was purchased from Bio-Rad (USA); and a DNA ladder with stain was purchased from SibEnzyme (Russia). All other reagents used in this study were purchased from Sigma-Aldrich (USA).

\section{Plants}

G. daltonii, C. orientalis, C. speciosum, A. tatarinowii, A. villosum and $P$. kesiya, were collected from Chaiyaphum province, Thailand and authenticated visually according to a taxonomic method by Assistant Professor Thaweesak Thitimetharoch. The vouchers of the specimens (Table 1) were deposited at the herbarium of the Faculty of Pharmaceutical Sciences, Khon Kaen University, Khon Kaen province, Thailand.

\section{Extraction}

Dried plants were cut and macerated with $50 \%$ ethanol and water (1 g:6 ml) for seven days with occasional shaking. The solvent was filtered, distilled in vacuo with a rotary evaporator below $40^{\circ} \mathrm{C}$, and freeze-dried to obtain the crude extracts. The percent yields of the extracts and their parts used are shown in Table 2.

\section{HPLC analysis}

The HPLC fingerprints of the plant crude extracts were determined by an Agilent 1100 series (USA) with a pumping system (G1310A), a manual injector (G1328B) and a variable UV-Vis wavelength detector (G1314A). Chromatographic separation was performed with a HiQ Sil $\mathrm{C}_{18} \mathrm{~W}$ reversed-phase column $(4.6 \mathrm{~mm}$ id $\times 250 \mathrm{~mm}$ ) with a $5 \mu \mathrm{m}$ particle size (KYA TECH, Japan). An isocratic reversed- phase HPLC was performed. The mobile phase consisted of $20 \%$ acetonitrile in $80 \%$ Milli-Q water, $0.1 \% \mathrm{H}_{3} \mathrm{PO}_{4}$. The flow rate of the mobile phase was maintained at $0.7 \mathrm{ml} / \mathrm{min}$ throughout the analysis
[7]. The detector wavelengths were set at 213 and 280 $\mathrm{nm}$. The reference standards were gallic acid, chlorogenic acid, catechin, epicatechin, caffeic acid, vanillic acid, vanillin, coumaric acid, ferulic acid and quercetin ( $1 \mathrm{mg} / \mathrm{ml}$ in DMSO), and were used to confirm their presence in the extract fraction. The extracts were dissolved in DMSO at a final concentration of $20 \mathrm{mg} / \mathrm{ml}$.

\section{Cell culture}

Human hepatocarcinoma (HepG2) and normal African green monkey kidney epithelial (Vero) cell lines were maintained at the Centre for Research and Development of Medical Diagnostic Laboratories, Khon Kaen University (Thailand). The cell culture medium was Dulbecco's modified Eagle's medium (DMEM) supplemented with $10 \%$ foetal bovine serum (FBS), 100 units $/ \mathrm{ml}$ penicillin and $100 \mu \mathrm{g} / \mathrm{ml}$ streptomycin. The cells were cultured at $37^{\circ} \mathrm{C}$ under a humidified atmosphere containing $5 \%$ $\mathrm{CO}_{2}$.

\section{Cytotoxic activity}

The crude extracts were dissolved in dimethyl sulfoxide (DMSO) at $20 \mathrm{mg} / \mathrm{ml}$ as stock solutions which were then diluted with DMEM to desired concentrations ranging from 10 to $500 \mu \mathrm{g} / \mathrm{ml}$. The final concentration of DMSO in each sample did not exceed $1 \% \mathrm{v} / \mathrm{v}$, to keep the cytotoxicity of DMSO at less than $10 \%$. The HepG2 cell line and normal Vero cell line were used as cell models. Cytotoxicity testing was performed with a neutral red (NR) method [8]. Melphalan was used as a standard anticancer drug for comparison with the crude extracts. Briefly, the cells were seeded in 96-well plates $\left(100 \mu \mathrm{l} /\right.$ well at a density of $3 \times 10^{5}$ cells $\left./ \mathrm{ml}\right)$ and treated with various concentrations of the samples for 24 hours. Then, cells were washed twice with $1 \times$ PBS and the supernatant was discarded. A total of $100 \mu \mathrm{l}$ NR solution $(50 \mu \mathrm{g} / \mathrm{ml})$ was added to each well and incubated at $37^{\circ} \mathrm{C}$ for another hour. NR was then dissolved by $100 \mu \mathrm{l}$ of $0.33 \% \mathrm{HCl}$. Absorbance of NR dye was detected by a dual-wavelength UV spectrometer (Anthos 2010; Biochrom, UK) at $520 \mathrm{~nm}$ with a $650 \mathrm{~nm}$ reference

Table 1 Samples of the selected plants

\begin{tabular}{|c|c|c|c|c|}
\hline Plant name & Family & Collection number & Plant habit & Part used \\
\hline $\begin{array}{l}\text { Glochidion daltonii } \\
\text { (MÜll. Arg.) Kurz }\end{array}$ & Euphorbiaceae & TT-OC-SK-839 & Tree & $\begin{array}{l}\text { Woody stem } \\
\text { and twig }\end{array}$ \\
\hline Cladogynos orientalis Zipp. ex Span & Euphorbiaceae & TT-OC-SK-912 & Shrub & Leaves \\
\hline Catimbium speciosum (Wendl.) Holtt. & Zingiberaceae & TT-OC-SK-857 & Herb & Rhizomes \\
\hline $\begin{array}{l}\text { Amomum villosum var. xanthioides } \\
\text { (Wallich ex Baker) T. L. Wu \& S. J. Chen }\end{array}$ & Zingiberaceae & TT-OC-SK-941 & Herb & $\begin{array}{l}\text { Pseudostem } \\
\text { and leaves }\end{array}$ \\
\hline Acorus tatarinowii Schott & Acoraceae & TT-OC-SK-849 & Herb & $\begin{array}{l}\text { Underground stem } \\
\text { (rhizomes) }\end{array}$ \\
\hline Pinus kesiya Royle & Pinaceae & TT-OC-SK-910 & Herb & Woody twig \\
\hline
\end{tabular}


Table 2 Percent yields and cytotoxic activities.

\begin{tabular}{|c|c|c|c|c|c|}
\hline \multirow[t]{2}{*}{ Sample } & \multirow[t]{2}{*}{ Part used } & \multirow[t]{2}{*}{ Percent yield } & \multicolumn{2}{|c|}{$\mathrm{IC}_{50}(\mu \mathrm{g} / \mathrm{ml}) \pm$ standard deviation (SD) } & \multirow[t]{2}{*}{$\mathrm{SI}^{\mathrm{c}}$} \\
\hline & & & HepG2 & Vero & \\
\hline Melphalan ${ }^{a}$ & & & $37.7 \pm 9.8$ & $59.9 \pm 3.2$ & 1.6 \\
\hline Glochidion daltonii & $\begin{array}{l}\text { Woody stem } \\
\text { and twig }\end{array}$ & 4.3 & $109.1 \pm 8.8$ & $38.7 \pm 10.0$ & 0.7 \\
\hline Cladogynos orientalis & Leaves & 7.4 & $402.0 \pm 4.3$ & $205.4 \pm 5.6$ & 0.5 \\
\hline Catimbium speciosum & Rhizomes & 2.6 & $55.7 \pm 8.1$ & $19.7 \pm 2.5$ & 0.4 \\
\hline Acorus tatarinowii & $\begin{array}{l}\text { Underground stem } \\
\text { (rhizomes), }\end{array}$ & 10.5 & $364.8 \pm 6.6$ & $182.5 \pm 2.1$ & 0.5 \\
\hline Amommum villosum & $\begin{array}{l}\text { Pseudostem } \\
\text { and leaves }\end{array}$ & 7.21 & $119.2 \pm 8.6$ & Inactive $^{b}$ & $>4.2$ \\
\hline Pinus kesiya & Woody twig & 2.2 & $52.0 \pm 5.8$ & Inactive ${ }^{b}$ & 9.6 \\
\hline
\end{tabular}

Percent yields of the crude extracts from six indigenous plants and their cytotoxic activities after 24-hour treatment in human hepatocarcinoma (HepG2) and normal African green monkey kidney epithelial (Vero) cell lines.

Data are expressed as the means of triplication.

a Standard anticancer drug and positive control.

${ }^{b} \mathrm{IC}_{50}>500 \mu \mathrm{g} / \mathrm{ml}$ is considered to be inactive.

c $\mathrm{SI}$ refers to Selectivity Index, SI value > 3 indicating high selectivity [9].

wavelength. The percentage of cytotoxicity compared to the untreated cells was determined with the equation given below. A plot of \% cytotoxicity versus sample concentrations was used to calculate the concentration which showed $50 \%$ cytotoxicity $\left(\mathrm{IC}_{50}\right)$.

Cytotoxicity $(\%)=[100 \times($ Absorbance of untreated group - Absorbance of treated group $] /$ Absorbance of untreated grou

The selectivity index (SI), which indicates the cytotoxic selectivity (ie safety) of the crude extract against cancer cells versus normal cells [9], was calculated from the $\mathrm{IC}_{50}$ of the crude sample in normal cells versus cancer cells.

\section{Apoptosis induction assay \\ Nuclear staining with DAPI fluorescent dye}

Apoptosis of nuclei was detected by a 4,6-diamidino-2phenylindole (DAPI) staining assay. DAPI dye is a fluorescent dye that stains the nuclear DNA of a cell and is therefore used to determine the effect of plant extracts on inducing morphological changes in the nuclei of cancer cells undergoing apoptosis [10]. Briefly, the HepG2 and Vero cell lines at $500 \mu \mathrm{l}\left(1 \times 10^{6}\right.$ cells/well $)$ were seeded on 24-well plates and incubated until cell growth at $\log$ phase for 24 hours. The cells were then treated at $2 \times \mathrm{IC}_{50}$ of each plant extract or melphalan (at the highest concentration of $500 \mu \mathrm{g} / \mathrm{ml}, 0.1 \%$ DMSO) for 24 hours. After treatment, the cells were washed with $1 \times$ PBS and then fixed with $50 \mu \mathrm{l}$ of methanol and water (1:1) under $-20^{\circ} \mathrm{C}$ for ten minutes. The fixed cells were washed and stained with $100 \mu \mathrm{l}(1 \mu \mathrm{g} / \mathrm{ml})$ of DAPI dye and then incubated at $37^{\circ} \mathrm{C}$ in a dark room for $30 \mathrm{~min}$ utes. The excess dye was then removed and $20 \mu \mathrm{l}$ of PBS:glycerin (1:1) was added to the mixed cells. The cells undergoing apoptosis, represented by the morphological changes of apoptotic nuclei, were observed and imaged from ten eye views at $40 \times$ magnifications under an inverted fluorescence microscope. Percentage of apoptotic cells was calculated as follows:

$\%$ apoptotic cells $=($ amount of apoptotic nuclei/amount of all cells $) \times 100$

\section{DNA fragmentation detection assay}

DNA fragmentation was used to determine the induction of apoptosis induction by observing the biochemical change $[11,12]$. Briefly, after cancer cells were treated with $2 \times \mathrm{IC}_{50}$ of crude extracts and melphalan for 24 hours, the cells were collected and washed with media. Then cell suspensions were transferred to microcentrifuge tubes $(1.5 \mathrm{ml})$ and centrifuged at $300 \times g$ (Wisd Laboratory instrument, Germany) for five minutes to collect the cell pellets. The DNA in the cell pellet was extracted with Flexigene DNA Kit (QIAGEN, Germany); $2 \mu \mathrm{g}$ of DNA was electrophoresed on $2 \%$ agarose gel containing $0.1 \mathrm{mg} / \mathrm{ml}$ ethidium bromide. After electrophoresis, DNA fragments were analyzed with a UV-illuminated camera (Syngene, UK).

\section{Alkylating activity assay}

The pyridine ring of nitrogen in 4-(4'-nitrobenzyl) pyridine (NBP) was used to test the alkylating ability of the test compounds in vitro. The pyridine ring 'nitrogen' in NBP models the DNA 'guanine nitrogen' and undergoes alkylation with the test compounds. The NBP assay was conducted with a slightly modified method described previously [13]. Briefly, the mixture solutions of the plant extracts and melphalan were added to a buffer (pH 4.0) solution and incubated at $70^{\circ} \mathrm{C}$ for 30 minutes with a solution of NBP in microcentrifuge tubes; they were then immediately mixed thoroughly. The mixture solutions were added (in a 1:1 ratio) to test plates in an ice bath containing absolute ethanol and $0.1 \mathrm{~N} \mathrm{NaOH}$. 
The blue colour of the alkylated product was measured for absorbance at $600 \mathrm{~nm}$ with a UV-Vis spectrophotometer.

\section{Statistical analysis}

Data were expressed as mean \pm standard deviation (SD, $n=3$ ). Statistical differences compared between multiple groups of the treated groups and untreated group were analyzed by one way analysis of variance (ANOVA) and followed by Turkey HSD with IBM SPSS version 17.0 (SPSS Inc., USA). Statistical analysis was considered significant if $P$ is less than 0.001 and within the $99.9 \%$ confidence interval.

\section{Results and Discussion}

\section{Chemical identification of plant crude extracts using}

\section{HPLC}

HPLC chromatograms were used as references for quality control in future experiments. Commonly found in these plants, the phenolic compounds and flavonoids were used as markers in our experiments. Pure compounds, namely gallic acid, chlorogenic acid, catechin, epicatechin, caffeic acid, vanillic acid, vanillin, coumaric acid, ferulic acid and quercetin, were used as marker compounds (Additional file 1). To confirm the existence of the markers in the crude extracts, we set the detection wavelengths at $213 \mathrm{~nm}$ and $280 \mathrm{~nm}$. Retention times of the same marker compound at the two wavelengths were found to be close. HPLC fingerprints of the crude extracts revealed that the peaks of the polyphenolic compounds and flavonoids occurred at the same retention times as the markers (Additional file 2), indicating that all crude extracts consisted of various types of polyphenolic and flavonoid contents (Table 3).
HPLC analysis was performed under specific conditions at specific wavelengths (ie 213 and $280 \mathrm{~nm}$ ) and specific mobile phase/stationary phase systems. Therefore, not all chemical compounds in the crude extract were detected. The detected compounds were those that separable under the HPLC conditions and had optimal absorbance at the wavelengths. HPLC fingerprints indicated only the presence of the standard compounds.

Cytotoxic effect of the plant crude extracts in HepG2 cells In vitro cytotoxicity test is mainly performed to screen potentially toxic compounds that affect basic cellular functions. This toxicity is measured with cellular damage using NR which is a weak cationic dye that penetrates and accumulates in the lysosomes of living cells [8]. Therefore, NR assay was used to determine the cell viability or, in other words, the toxicity of the test compounds. We found that all the crude extracts and melphalan showed significant cytotoxicity to HepG2 and Vero cells, with different $\mathrm{IC}_{50}$ values, when compared to the control $(P<0.001$, one-way ANOVA) (Table 2$)$. In HepG2 cells, no significant difference in mean cytotoxicity (one-way ANOVA) was observed between melphalan and C. speciosum $(P=0.003)$, melphalan and $P$. kesiya $(P=0.002), G$. daltonii and A. villosum $(P=0.964)$ as well as $C$. speciosum and $P$. kesiya $(P=1)$. In Vero cells, the mean cytotoxicity between the extracts of $A$. villosum and $P$. kesiya was not significantly different $(P=$ 1, one-way ANOVA) (Table 2). Melphalan showed the highest cytotoxicity to HepG2 cells but less selectivity. The extract of $P$. kesiya showed relatively high cytotoxicity. The extracts of $P$. kesiya and A. villosum were highly selective to HepG2 cells as compared to normal Vero cells. The extracts of G. daltonii, A. villosum, A.

Table 3 Amount of the polyphenolic and flavonoid compounds detected in the crude extracts from six indigenous plants.

\begin{tabular}{|c|c|c|c|c|c|c|c|}
\hline \multirow{2}{*}{\multicolumn{2}{|c|}{$\begin{array}{l}\text { Compound } \\
\text { (at } 213 \mathrm{~nm} \text { ) }\end{array}$}} & \multicolumn{6}{|c|}{ Amount detected (mg/g crude extracts) } \\
\hline & & \multirow{2}{*}{$\frac{\text { G. daltonii }}{32.6}$} & \multirow{2}{*}{$\begin{array}{l}\text { C. orentalis } \\
N D\end{array}$} & \multirow{2}{*}{$\begin{array}{l}\text { C. speciosum } \\
10.7\end{array}$} & \multirow{2}{*}{$\begin{array}{l}\text { A. villosum } \\
14.6\end{array}$} & \multirow{2}{*}{$\begin{array}{l}\text { A. tatarinowii } \\
11.1\end{array}$} & \multirow{2}{*}{$\begin{array}{l}\text { P. kesiya } \\
19.7\end{array}$} \\
\hline 1 & Gallic acid & & & & & & \\
\hline 2 & Chlorogenic acid & 4.2 & 53.2 & ND & 2.5 & ND & 10.1 \\
\hline 3 & Catechin & ND & 59.0 & ND & 1.4 & ND & ND \\
\hline 4 & Epicatechin & ND & 56.6 & ND & 1.4 & ND & ND \\
\hline 5 & Caffeic acid & ND & ND & ND & ND & ND & 5.0 \\
\hline 6 & Vanillic acid & ND & 23.1 & ND & ND & 4.6 & ND \\
\hline 7 & Vanillin & ND & 4.1 & ND & ND & ND & 5.0 \\
\hline 8 & Coumaric acid & ND & 4.0 & ND & ND & 1.3 & 3.1 \\
\hline 9 & Ferulic acid & ND & ND & ND & 1.5 & 1.4 & ND \\
\hline 10 & Quercetin & ND & 114.3 & ND & ND & ND & ND \\
\hline
\end{tabular}

The amount of the compounds in the crude extracts was calculated from the HPLC chromatograms detected at wavelength $213 \mathrm{~nm}$ under the condition as described in the Methods section.

ND $=$ not detected. 
tatarinowii and $C$. orientalis were also cytotoxic to HepG2 cells, with $\mathrm{IC}_{50}$ values higher than $100 \mu \mathrm{g} / \mathrm{ml}$. Extract of A. villosum was selective to HepG2 cells.

\section{Apoptosis induction effect of the plant crude extracts in HepG2 cells}

The plant crude extracts were further evaluated for cancer apoptotic death mode. Apoptosis is the pharmacodynamic endpoint of anticancer drug therapy as this phenomenon ensures that no cancer resistance to chemotherapy will occur [11]. Moreover, apoptosis is an autonomous dismantled process to remove individual components of cells and avoids inflammatory effect normally associated with necrosis; thus no toxicity to the normal surrounding cells will occur when cells undergo apoptosis $[10,11]$. To investigate whether the cytotoxic effects of the crude extracts were due to apoptosis, we treated the HepG2 cells with the plant extracts at $2 \times \mathrm{IC}_{50}$ for 24 hours. In the control or untreated HepG2 cells, the stained nuclei were rounded and homogenously stained with DAPI (Figure $1)$. The treated cancer cells showed different stained DNA nuclei from the control group, by presenting condensed chromatin and apoptotic bodies that are the typical of the early and late stages of apoptosis (Figure 1 ). According to the statistical analysis of HepG2 cells, melphalan, C. orientalis, C. speciosum, A. tatarinowii and P. kesiya exhibited apoptosis (in percentage) significantly different from the untreated or control group $(P<0.001$, one-way ANOVA). However, no significant difference of apoptosis was observed (one-way ANOVA) between the extracts of either A. villosum $(P=0.967)$ or $G$. daltonii $(P=0.003)$ and the control. The positive control treated with melphalan showed well-separated apoptotic bodies, indicative of the late stage of apoptosis [12] (Figure 1). HepG2 cells treated with $2 \times \mathrm{IC}_{50}$ crude extracts from $P$. kesiya, C. speciosum and $C$. orientalis underwent both early and later stages of apoptosis and showed over $30 \%$ of apoptotic cells, as observed from nuclear shrinkage, chromatin condensation or apoptotic bodies (after 24 hours of exposure). Extract of $P$. kesiya induced $79.8 \pm 8.9 \%$ apoptosis in HepG2 cells, which is not significantly different $(P=1$, one-way ANOVA) from melphalan (80.0 $\pm 2.8 \%)$. Extract of A. tatarinowii showed $28.3 \pm 3.1 \%$ of apoptotic cells mostly in the early state of apoptosis. This early stage of apoptosis was barely observed in the cells treated with the extracts from G. daltonii and A. villosum which showed less than $10 \%$ apoptotic cells (Figure 1). No significant difference was observed (one-way ANOVA) between G. daltonii and A. villosum $(P=0.046), C$. orientalis and $A$. tatarinowii $(P=$ 0.029), C. orientalis and $C$. speciosum $(P=1)$ as well as C. speciosum and A. tatarinowii $(P=0.011)$.
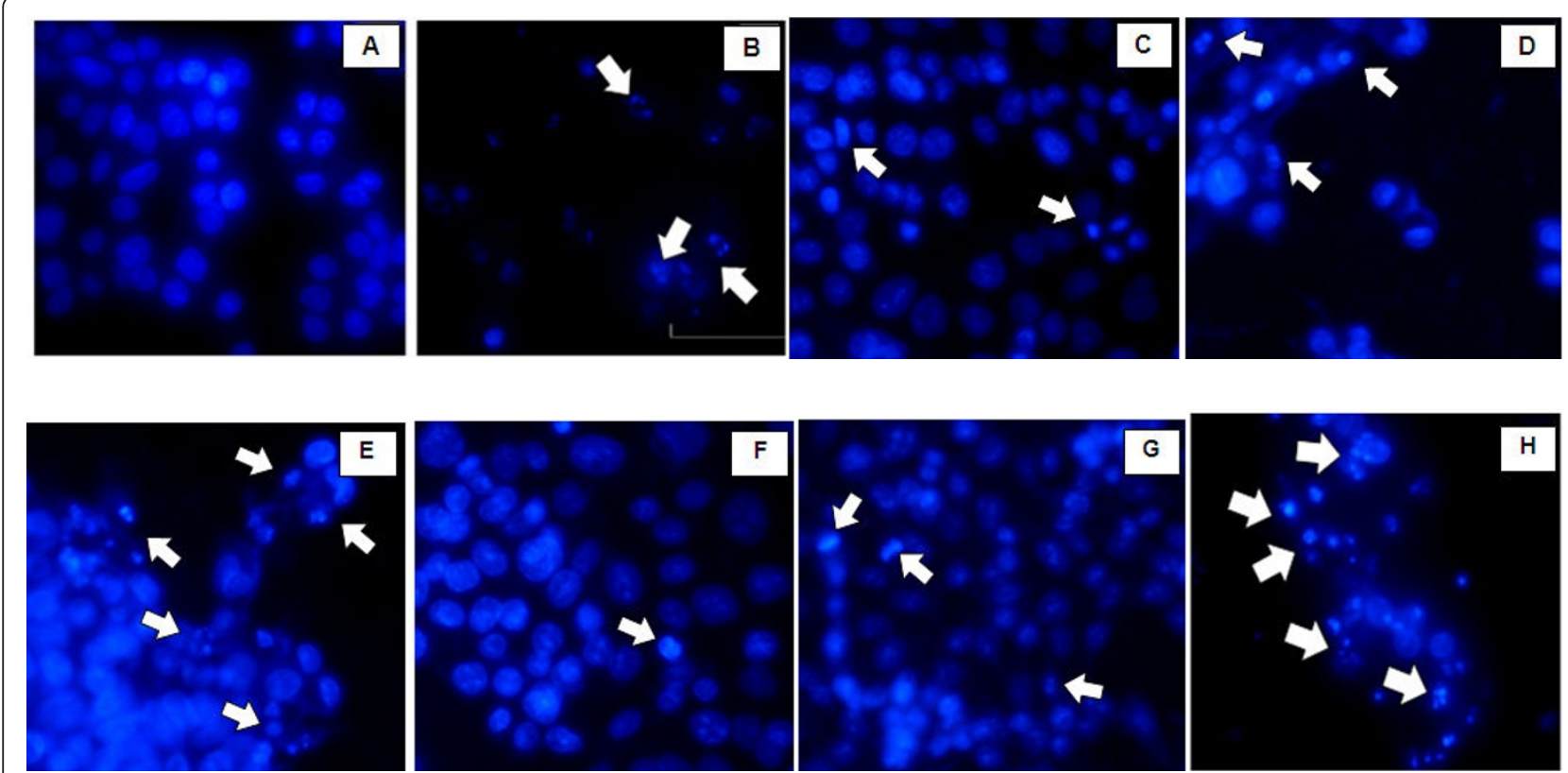

Figure 1 Nuclear morphological changes. Nuclear morphological changes in HepG2 cells after treatment with $2 \times I_{50}$ of crude extracts for 24 hours followed by DAPI staining. (A) Control cells treated with media; (B) melphalan-treated group $(80 \mu \mathrm{g} / \mathrm{ml})$. (C-H) cells treated with

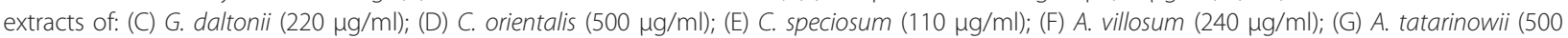
$\mu \mathrm{g} / \mathrm{ml})$; and $(\mathrm{H})$ Pinus kesiya $(110 \mu \mathrm{g} / \mathrm{ml})$. Arrows indicate apoptotic bodies of nuclear fragmentation observed at $40 \times$ magnification under an inverted fluorescence microscope. 


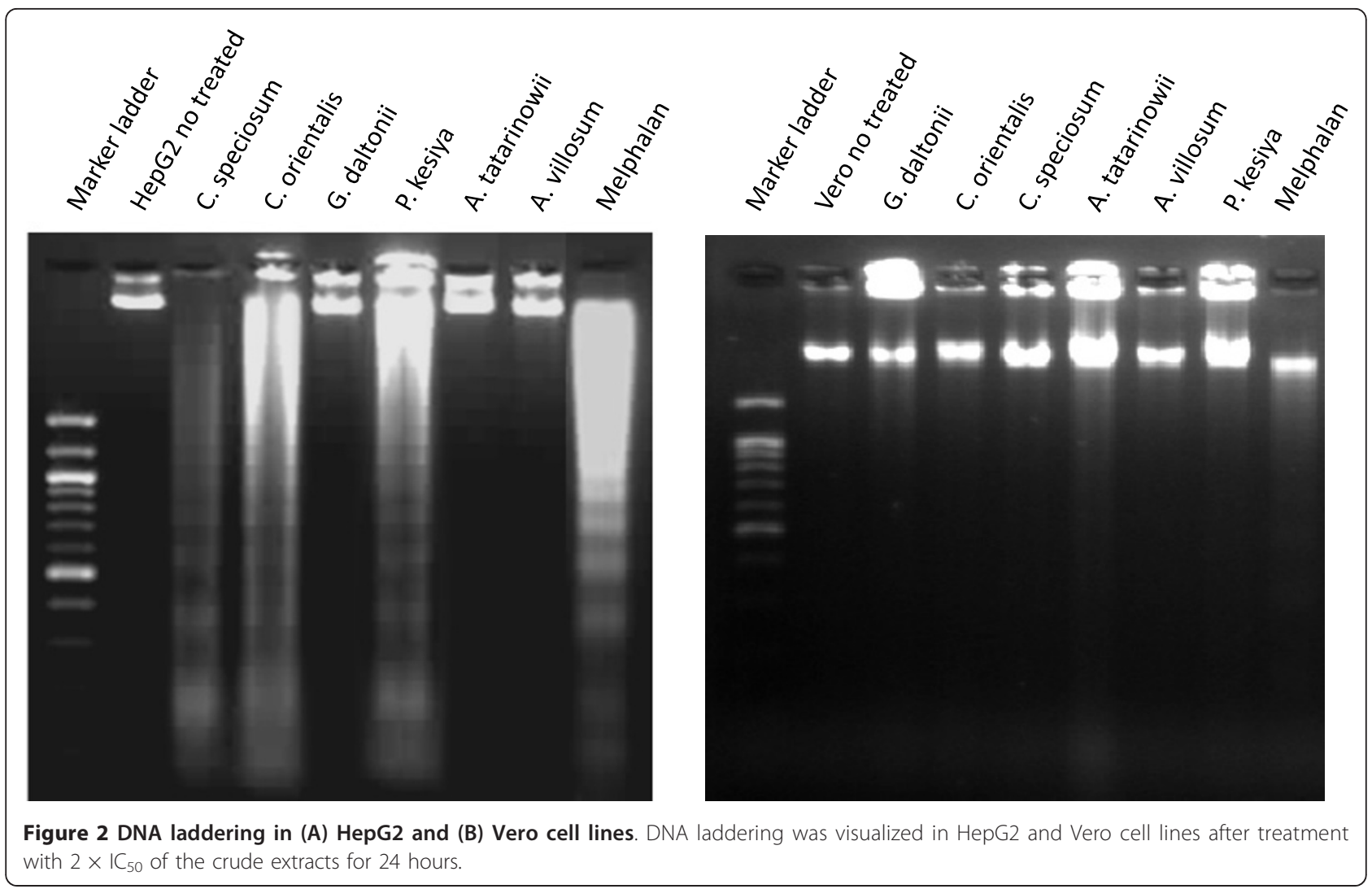

Evaluation of apoptosis was further carried out by determining the DNA laddering as a result of DNA fragmentation, indicative of the late stage of apoptosis [12] (Figure 2A). HepG2 cells treated with the extracts of $C$. speciosum, C. orientalis and P. kesiya showed characteristics of DNA laddering.

Interestingly, the cell samples treated with the extracts of C. speciosum and P. kesiya, which had apoptotic cells higher than 30\%, also showed DNA laddering in HepG2 cells (Table 4). It should be noted that the extract of $P$. kesiya was very selective to HepG2 cells $(\mathrm{SI}=9.6)$ as compared to its cytotoxicity in normal Vero cells. The relatively low cytotoxic extract of $C$. orientalis was also

Table 4 Apoptotic effects of the six plant extracts on HepG2 cells

\begin{tabular}{lll}
\hline $\begin{array}{l}\text { Plant } \\
\text { sample }\end{array}$ & $\begin{array}{l}\text { Percentage of apoptotic cells (mean } \pm \\
\text { SD) }\end{array}$ & $\begin{array}{l}\text { DNA } \\
\text { ladder }\end{array}$ \\
\hline Melphalan & $80.0 \pm 2.8$ & + \\
G. daltonii & $10.1 \pm 4.8$ & - \\
C. orientalis & $31.9 \pm 3.9$ & + \\
C. speciosum & $36.5 \pm 8.1$ & + \\
A. tatarinowii & $28.3 \pm 3.1$ & - \\
A. villosum & $3.3 \pm 1.2$ & - \\
P. kesiya & $79.8 \pm 8.9$ & + \\
\hline
\end{tabular}

found to cause DNA laddering. The extracts of G. daltonii, A. villosum and A. tatarinowii that possessed low cytotoxicity showed apoptotic cells of less than 30 .

\section{Alkylating activity of the plant extracts}

Results of the NBP assay were used to estimate the mechanism of the DNA damage of many anticancer agents in vitro via DNA alkylating activity. The alkylating activities of the plant crude extracts [14] are shown in Table 5. All plant extracts showed significantly

Table 5 Alkylating activities of the six plant extracts and melphalan

\begin{tabular}{lll}
\hline Sample & $\begin{array}{l}\text { Absorbance } \\
\left(\boldsymbol{\lambda}_{\max }=600\right. \\
\mathbf{n m})\end{array}$ & Alkylation activities \\
\hline Melphalan & 2.768 & $\begin{array}{l}\text { Absorbance }>0.50 \\
\text { (very high alkylating } \\
\text { activities) }\end{array}$ \\
$\begin{array}{l}\text { G. daltonii } \\
\begin{array}{l}\text { A. villosum var } \\
\text { C. onthioides }\end{array}\end{array}$ & 0.745 & $\begin{array}{l}0.15 \geq \text { Absorbance } \geq 0.50 \\
\text { (high alkylating activities) }\end{array}$ \\
$\begin{array}{l}\text { P. kesiya } \\
\text { C. speciosum }\end{array}$ & 0.464 & \\
\hline A. tatarinowii & 0.273 & $\begin{array}{l}\text { Absorbance }<0.15 \\
\text { (low alkylating activities) }\end{array}$ \\
\hline
\end{tabular}


different alkylating activity in vitro compared to melphalan $(P<0.001$, one-way ANOVA). Melphalan and the extract of $G$. daltonii showed relatively high alkylating activity, with absorbance higher than 0.5. The extracts of A. villosum, C. orientalis, P. kesiya and C. speciosum showed moderate alkylating activity, with absorbance ranging $0.15-0.5$. The $A$. tatarinowii extract showed very low alkylating activity, with an absorbance of 0.135; however, no significant difference of alkylating activity was observed between $C$. speciosum and A. tatarinowii $(P=0.002$, one-way ANOVA).

It should be noted that this DNA alkylating activity could predict the DNA damage caused by the compound in the cells although it is not the cell-based assay. And since selective anticancer activity in the cancer cells is more preferable, therefore, the DNA fragmentation assay was also conducted in the Vero cells. Results demonstrated that the crude extracts as well as melphalan did not induce DNA fragmentation or apoptosis effect in the normal Vero cells (Figure $2 \mathrm{~B})$. The constituents found in the plant crude extracts might alkylate the DNA and cause DNA strand breakage and damage, leading to the cancer cell death. Our finding demonstrated that all crude extracts possessed selective apoptosis induction effect only in the HepG2 cells.

Extract of C. speciosum induced high cytotoxicity, apoptosis rates and possessed ability to damage DNA whereas other herbs with more phenolic and flavonoids ingredients had not such anticancer effects. As the UV detector of the HPLC detected the presence of the compounds based on their maximum absorbance at the specific wavelength under specific conditions, not all chemical compounds in the crude extract of C. speciosum were detected. This might also be the case for the other herbs as well.

Many studies have suggested that the marker compounds used in our study were the active phytochemicals with anti-cancer, anti-invasive and anti-metastatic activities in cancer cells [15-17]. These phenolic and flavonoid compounds induced apoptosis via the cell cycle arrest progression, increasing pro-protein (Bax and $\mathrm{Bad}$ ) levels and decreasing anti-apoptotic protein levels (Bcl-2 and Bcl-xL) in the HepG2 cells [15,18-25]. Therefore, the presence of phenolic and flavonoid compounds in the crude extracts was partly attributable to the anticancer activity of the crude extracts.

However, some other active anticancer constituents in the crude extracts may not have been identified under the current HPLC conditions. Extract of C. speciosum or P. kesiya which contained fewer polyphenols (Table 3) appeared to have strong anticancer activity in the HepG2 cells (Table 2).

\section{Conclusion}

The extracts of C. speciosum, C. orientalis and P. kesiya induced apoptosis. Among the three plants, P. kesiya possessed the most robust anticancer activity, with specific selectivity against HepG2 cells.

\section{Additional material}

\begin{abstract}
Additional file 1: HPLC chromatograms of the polyphenolic compounds and flavonoids. Column: HiQ-Sil $\mathrm{C}_{18} \mathrm{~W}$ reversed-phase column; flow rate, $0.7 \mathrm{ml} / \mathrm{min}$. The mobile phase consisted of $20 \%$ acetonitrile in $80 \%$ Milli-Q water, $0.1 \% \mathrm{H}_{3} \mathrm{PO}_{4}$ detected at $213 \mathrm{~nm}$ (left) and $280 \mathrm{~nm}$ (right). (A) gallic acid; (B) chlorogenic acid; (C) catechin; (D) epicatechin; (E) caffeic acid; $(F)$ vanillic acid; $(G)$ vanillin; $(H)$ coumaric acid (I) ferulic acid; (J) quercetin; and (K) solvent front or DMSO.

Additional file 2: HPLC fingerprints of the crude extracts. Column: $\mathrm{HiQ}-\mathrm{Sil}$ C18W reversed-phase column; flow rate, $0.7 \mathrm{ml}$ per minute. The mobile phase consisted of $20 \%$ acetonitrile in $80 \%$ Milli-Q water, $0.1 \%$ $\mathrm{H}_{3} \mathrm{PO}_{4}$ detected at $213 \mathrm{~nm}$ (left) and $280 \mathrm{~nm}$ (right). (A) G. daltonii extract; (B) C. orientalis extract; (C) C. speciosum extract; (D) A. tatarinowii extract; (E) A. villosum extract; and (F) P. kesiya extract.
\end{abstract}

\begin{abstract}
Abbreviations
DAPI: 4',6-diamidino-2-phenylindole; DMEM: Dulbecco's modified Eagle's medium; DMSO: dimethyl sulfoxide; FBS: foetal bovine serum; $\mathrm{NaOH}$ : sodium hydroxide; NBP: 4-(4'-nitrobenzyl) pyridine; NR: neutral red; HepG2: human hepatocarcinoma cell line; HPLC: high performance liquid chromatography; PBS: phosphate buffer solution; Vero: normal African green monkey kidney epithelial cell line; NCl: National Cancer Institute (USA)
\end{abstract}

\section{Acknowledgements}

SM is grateful to the Office of the Higher Education Commission, Thailand, for a scholarship under the program Strategic Scholarships for Frontier Research for the PhD Program Thai Doctoral Degree (CHE-PhD-THA-RG 3/ 2549). The authors thank the Plant Genetics Conservation Project under the Royal Initiation of her Royal Highness Princess Maha Chakri Sirindhorn, The Bureau of The Royal Household for permission to conduct the research and Electricity Generating Authority of Thailand (EGAT) for field support.

\section{Author details}

${ }^{1}$ Graduate School, Faculty of Pharmaceutical Sciences, Khon Kaen University, Khon Kaen 40002, Thailand. ${ }^{2}$ Center for Research and Development of Herbal Health Products, Division of Pharmaceutical Chemistry, Faculty of Pharmaceutical Sciences, Khon Kaen University, Khon Kaen 40002, Thailand. ${ }^{3}$ Centre for Research and Development of Medical Diagnostic Laboratories (CMDL), Faculty of Associated Medical Sciences, Khon Kaen University, Khon Kaen 40002, Thailand.

\section{Authors' contributions}

NW designed the study. SM performed the experiments. $\Pi$ performed plant authentication. BS carried out plant extraction. SM, AN, NW reviewed the literature and analyzed study results. SB and AN helped draft manuscript and coordinate. SM and NW wrote the manuscript. NW revised the final version of the manuscript. All authors read and approved the final version of the manuscript.

\section{Competing interests}

The authors declare that they have no competing interests.

Received: 13 August 2011 Accepted: 31 October 2011

Published: 31 October 2011

\section{References}

1. Frei E: The national cancer chemotherapy program. Science 1982, 217:600-606. 
2. Johnson IS, Armstrong JG, Gorman M, Burnett JP: The vinca alkaloids: A new class of oncolytic agents. Cancer Res 1963, 23:1390-1427.

3. Wani C, Taylor HL, Wall ME, Coggon P, McPhail A: Plant antitumor agents VI. The isolation and structure of taxol, a novel antileukemic and antitumor agent from Taxus brevifolia. J Amer Chem Soc 1971, 93:2325-2327.

4. Wall MEMC, Wani CE, Cook KH, Palmer ATM, Sim GA: Plant Antitumor Agents. I. The isolation and structure of camptothecin, a novel alkaloidal leukemia and tumor inhibitor from Camptotheca acuminata. J Amer Chem Soc 1966, 88:3888-3890.

5. Moon JY, Mosaddik A, Kim H, Cho M, Choi H-K, Kim YS, Cho SK: The chloroform fraction of guava (Psidium cattleianum sabine) leaf extract inhibits human gastric cancer cell proliferation via induction of apoptosis. Food Chem 2011, , 125: 369-375.

6. Chen T-J, Jeng J-Y, Lin C-W, Wu C-Y, Chen Y-C: Quercetin inhibition of ROS-dependent and independent apoptosis in rat glioma C6 cells. Toxicology 2006, 1-2:113-126.

7. Prayong P, Weerapreeyakul N, Sripanidkulch B: Validation of isocratic eluting and stepwise flow rate gradient for HPLC determination of catechins, gallic acid and caffeine in tea. Science Asia 2007, 33:113-117.

8. Fotakis $G$, Timbrell JA: In vitro cytotoxicity assays: Comparison of $L D H$, neutral red, MTT and protein assay in hepatoma cell lines following exposure to cadmium chloride. Toxicol Lett 2006, 160:171-177.

9. Prayong P, Barusrux S, Weerapreeyakul N: Cytotoxic activity screening of some indigenous Thai plants. Fitoterapia 2008, 79:598-601.

10. Gallardo-Escárate C, Álvarez-Borrego J, Brand EV, Dupré E, Río-Portilla MAD Relationship between DAPI-fluorescence fading and nuclear DNA content: An alternative method to DNA quantification? Biol Res 2007, 40:29-40.

11. Elmore S: Apoptosis: a review of programmed cell death. Toxicol Pathol 2007, 35:495-516.

12. Kalinina TS, Bannova AV, Dygalo NN: Quantitative evaluation of DNA fragmentation. Bull Exp Biol Med 2002, 134:554-556.

13. Thomas JJ, Kim JH, Maur DM: 4-(4-Nitrobenzyl)pyridine tests for alkylating agents following chemical oxidative activation. Arch Environ Con Tox 1992, 22:219-227.

14. Budzisz E, Brzezinska E, Krajewska U, Rozalski M: Cytotoxic effects, alkylating properties and molecular modelling of coumarin derivatives and their phosphonic analogues. Eur J Med Chem 2003, 38:597-603.

15. Ramos S, Alia M, Bravo L, Goya L: Comparative effects of food-derived polyphenols on the viability and apoptosis of a human hepatoma cell line (HepG2). J Agric Food Chem 2005, , 53: 1271-1280.

16. Weng CJ, Yen GC: Chemopreventive effects of dietary phytochemicals against cancer invasion and metastasis: Phenolic acids, monophenol, polyphenol, and their derivatives. Cancer Treat Rev 2011

17. Kang NJ, Lee KW, Kim BH, Bode AM, Lee HJ, Heo YS, Boardman L, Limburg P, Lee HJ, Dong Z: Coffee phenolic phytochemicals suppress colon cancer metastasis by targeting MEK and TOPK. Carcinogenesis 2011, 32:921-928.

18. Ho K, Yazan LS, Ismail N, Ismail M: Apoptosis and cell cycle arrest of human colorectal cancer cell line HT-29 induced by vanillin. Cancer Epidemiol 2009, 33:155-160

19. Naowaratwattana W, De-Eknamkul W, De Mejia EG: Phenolic-containing organic extracts of mulberry (Morus alba L.) leaves inhibit HepG2 hepatoma cells through G2/M phase arrest, induction of apoptosis, and inhibition of topoisomerase llalpha activity. J Med Food 2010, 13:1045-1056.

20. Wang GF, Shi LP, Ren YD, Liu QF, Liu HF, Zhang RJ, Li Z, Zhu FH, He PL, Tang W, Tao PZ, Li C, Zhao WM, Zuo JP: Anti-hepatitis B virus activity of chlorogenic acid, quinic acid and caffeic acid in vivo and in vitro. Antiviral Res 2009, 83:186-190.

21. Lee YS: Role of NADPH oxidase-mediated generation of reactive oxygen species in the mechanism of apoptosis induced by phenolic acids in HepG2 human hepatoma cells. Arch Pharm Res 2005, 28:1183-1189.

22. Haza Al, Morales P: Effects of (+)-catechin and (-)-epicatechin on heterocyclic amines-induced oxidative DNA damage. J App/ Toxicol 2011, 31:53-62.

23. Granado-Serrano AB, Martin MA, Haegeman G, Goya L, Bravo L, Ramos S: Epicatechin induces NF-kappaB, activator protein-1 (AP-1) and nuclear transcription factor erythroid 2p45-related factor-2 (Nrf2) via phosphatidylinositol-3-kinase/protein kinase B (PI3K/AKT) and extracellular regulated kinase (ERK) signalling in HepG2 cells. Br J Nutr 2010, 103:168-179.

24. Granado-Serrano AB, Martin MA, Izquierdo-Pulido M, Goya L, Bravo L, Ramos S: Molecular mechanisms of (-)-epicatechin and chlorogenic acid on the regulation of the apoptotic and survival/proliferation pathways in a human hepatoma cell line. J Agric Food Chem 2007, 55:2020-2027.

25. Janicke B, Hegardt C, Krogh M, Onning G, Akesson B, Cirenajwis HM Oredsson SM: The antiproliferative effect of dietary fiber phenolic compounds ferulic acid and p-coumaric acid on the cell cycle of Caco-2 cells. Nutr Cancer 2011, 63:611-622.

doi:10.1186/1749-8546-6-39

Cite this article as: Machana et al: Cytotoxic and apoptotic effects of six herbal plants against the human hepatocarcinoma (HepG2) cell line. Chinese Medicine 2011 6:39.

\section{Submit your next manuscript to BioMed Central and take full advantage of:}

- Convenient online submission

- Thorough peer review

- No space constraints or color figure charges

- Immediate publication on acceptance

- Inclusion in PubMed, CAS, Scopus and Google Scholar

- Research which is freely available for redistribution
Ciomed Central 